получает систему аксиологических взаимосвязей земли и работы с другими ценностями, такими как жизнь, пища, плодородие, достаток, богатство, трудолюбие, удовлетворение, общественное признание, доверие, взаимодействие, взаимность, справедливость, равенство, солидарность, нравственный порядок, святость, Бог, уважение, достоинство, честь, традиция, музыка, красота - вплоть до родного края, локальной общности, вотчины, дома, матери, этнической родины и родной страны.

Пер. с польск. Е. О. Борисовой

DOI 10.31168/7996-2700-3.84

\author{
Александра Невяра \\ Силезский университет \\ Катовице, Польша \\ aleksandra.niewiara@us.edu.pl
}

\title{
Концепции коллективного времени как фактор польской идентичности
}

Коллективное время - это время, которое сообщество переживает вместе, а также время, которое хранится в коллективной памяти. Научные теории о коллективном времени (или социальном времени) и коллективной памяти возникли в социологических трудах в первой половине XX в. [Tarkowska, 1987; Saryusz-Wolska, Traba, 2014]. В наши дни их влияние распространилось на всю гуманитарную науку, не исключая этнолингвистику.

Этнолингвистические исследования могут описывать фольклорное и религиозное течение времени [Szadura, 2017, 253-297], но могут быть направлены на изучение этнической общности, которая воспринимает себя отдельно от других из-за своего языка, государства, страны, культуры, истории. Таким образом, мы можем говорить о времени поляков, русских, англичан или французов. Мы можем также, основываясь на текстах разных исторических периодов, наблюдать, как коллективное время представлялось в определенный период, и делать выводы о его эволюции. В докладе автор представит результаты анализа польских

(C) Невяра А., 2019 
мемуаров и дневников XVI-XX вв. [Niewiara, 2009] и польской прессы после Второй мировой войны [Niewiara, в печати].

В польских текстах XVI, XVII и XVIII вв. мы обнаруживаем, что польское время (время Речи Посполитой и ее граждан) понимается как линейное и телеологическое. Однако существуют большие различия в трактовке времени на протяжении этих трех веков. В XVI и XVII вв. поляки положительно относятся к ходу своей истории и верят в покровительство Бога. Они думают об истоках сообщества и планируют его будущее. В ежедневных записях, в воспоминаниях о жизни они ищут начало своей общности в каком-то неуказанном старопольском (staropolskim) периоде и ссылаются на поколения своих бабушек и дедушек, а будущее ограничивают всего лишь временем внуков.

В XVII в. горизонт польского времени простирается гораздо дальше - как в прошлое, так и в будущее. Авторы дневников сравнивают свое настоящее с временами древних римлян и греков, в которых царила такая же рыцарская смелость и благородство; они верят, что их произведения будут помнить вечно. Такое восприятие времени характерно для периода процветания Речи Посполитой и согласуется с ее политическими амбициями.

В XVIII в., когда государство приходит в упадок, вера поляков в защиту Бога ослабевает. Телеологическое видение истории уже не проникнуто оптимизмом. После 1795 г. настоящее определяется как конец Польши (finis Poloniae), ее смерть (śmierć, zguba); прошлое как зло, которое привело к поражению (возникают сравнения с судьбой ветхозаветных евреев, справедливо наказанных Богом за грехи); будущее - как время праправнуков, которые будут презирать ныне живущих. В континууме польского времени обнаруживается разрыв. Лекарством от такого состояния коллективной души становится разговор о жизни поляков как о сне, летаргии (fatalny letarg), в которую погрузилось общество.

В XIX в. концепция времени меняется - приходит циклическое видение, благодаря которому можно поверить в возвращение Польши после оборота колеса времени. Как мы знаем из польской литературы, способ справиться со злой судьбой - это вновь довериться Богу и принять телеологическое видение времени, так как цель поляков на земле состоит в том, чтобы повторить жертву Христа и искупить вину народов мира (Polska Chrystusem narodów). В обоих случаях будущее бесконечно 
далеко, а настоящее не имеет большого значения. Цель человека пожертвовать своей жизнью ради будущей победы.

В XX в. наблюдается развитие прежних концепций. Остается память о прошлом разрыве в истории (Polska opuściła w swych dziejach wiek dziewiętnasty «Польша пропустила в своей истории век девятнадцатый»). Разрывы ощущаются сильнее - время в XX в. представляется фрагментированным и разделеным на четыре сегмента (II Rzeczpospolita, Polska Rzeczpospolita Ludowa, III Rzeczpospolita, IV Rzeczpospolita), а история полна белых пятен. Линейные и циклические представления о времени также сохраняются. Циклическое видение - в комментариях о восстаниях против системы коммунистического государства, которые повторяются каждые десять лет (co dziesięć lat nowe powstanie), о «польском календаре» с месяцами, написанными с заглавных букв (Czerwiec 'июнь 1956 г.', Marzec 'март 1968 г.', Grudzień ‘декабрь 1970 г.', Sierpień ‘август 1980 г.’). Линейная концепция времени сильна только в некоторые периоды: после Первой мировой войны, когда Польша восстанавливает независимость, во время Второй мировой войны, когда поляки сражаются против врага, и в последние десятилетия XX в., во время понтификата Иоанна Павла II (papież Polak), появления Солидарности, трансформации политической системы. Интересно, что даже в это время в текстах публичного и частного дискурса можно увидеть четкое восприятие настоящего и прошлого - и размытость будущего. Сообщество не знает, какими будут его следующие преобразования.

Концепции времени сообщества отражают его духовное состояние. Они также информируют о действиях сообщества, направленных на обеспечение его устойчивости.

Niewiara A. Kształty polskiej tożsamości. Potoczny dyskurs narodowy w perspektywie etnolingwistycznej (XVI-XX wiek). Katowice, 2009.

Niewiara A. Imagologia — pamięć zbiorowa - dyskurs prasowy. В печати.

Saryusz-Wolska M., Traba R. Modi memorandi. Leksykon kultury pamięci. Warszawa, 2014.

Szadura J. Czas jako kategoria językowo-kulturowa w polszczyźnie. Lublin, 2017.

Tarkowska E. Czas w społeczeństwie. Problemy, tradycje, kierunki badań. Warszawa, 1987. 